Rosyadi/ 2017

\title{
KOMPARASI EFISIENSI PERBANKAN SYARIAH DAN PERBANKAN KONVENSIONAL DI INDONESIA
}

\author{
Imron Rosyadi ${ }^{1}$ \\ * Fakultas Ekonomi dan Bisnis Universitas Muhammadiyah Surakarta \\ *mron.ums@ac.id ${ }^{l}$
}

\begin{abstract}
The purpose of this study was to: (i) acknowledge and examine the differences between the financial performance of Islamic banking with conventional banking, (ii) to analyze and explain the differences in efficiency levels between Islamic banking and conventional banking (iii) analyze and compare the efficiency of Islamic banking with banks conventional. The population used in this study is a commercial bank in Indonesia with 124 banking institutions with the details of five state banks and 119 private banks. sample of banking institutions in this study are 5 government-owned banking institution (s) and 12 institutions of Islamic banks. The method of analysis used in quantitative research is descriptive (analytic). Measurement and test efficiency and efficiency ratio of the difference of Islamic banking from conventional banking to use Supplier Data Analysis (DEA) and two different test mean ( $t$-test). The results showed during the observation period 2012-2016, economic activities (banking) of Islamic banks are relatively more efficient than conventional banks
\end{abstract}

Keywords: comparative, efficiency, financial performance

\section{Pendahuluan}

Perbankan Indonesia dalam menjalankan fungsinya berasaskan prinsip kehati-hatian. Fungsi utama perbankan Indonesia adalah sebagai penghimpun dan penyalur dana masyarakat serta bertujuan untuk menunjang pelaksanaan pembangunan nasional dalam rangka meningkatkan pemerataan pembangunan dan hasil-hasilnya, pertumbuhan ekonomi dan stabilitas nasional, kearah peningkatan taraf hidup rakyat banyak. Berdasarkan undangundang, struktur perbankan di Indonesia, terdiri atas bank umum dan BPR. Perbedaan utama bank umum dan BPR adalah dalam hal kegiatan operasionalnya. BPR tidak dapat menciptakan uang giral, dan memiliki jangkauan dan kegiatan operasional yang terbatas. Selanjutnya, dalam kegiatan usahanya dianut dual bank system, yaitu bank umum dapat melaksanakan kegiatan usaha bank konvensional dan atau berdasarkan prinsip syariah. Sementara prinsip kegiatan BPR dibatasi pada hanya dapat melakukan kegiatan usaha bank konvensional atau berdasarkan prinsip syariah.

Struktur institusi perbankan di Indonesia sampai November 2016 terdiri dari 118 Bank Umum dan 1.796 Bank Perkreditan Rakyat. Adapun jumlah
Bank Umum dengan rincian: (1) Bank Pemerintah sebanyak 5 institusi dan (2) Bank Swasta, terdiri dari: (a) Bank Pembangunan Daerah sebanyak 26 institusi dan BPD unit syariah sebanyak 15 institusi (b) Bank Umum Swasta sebanyak 88 institusi dan Bank Umum Swasta Unit Usaha Syariah sebanyak 21 institusi serta (c) Bank Umum Swasta Syariah sebanyak 13 institusi. Sementara Bank Perkreditan Rakyat terdiri dari 1.632 institusi BPR konvensional dan 164 institusi BPR syariah (OJK, 2016)

OJK (2016) melaporkan beberapa indikator Perbankan Nasional berdasarkan penghimpunan dana, penyaluran dana, asset, permodalan dan kinerja. Pada November 2016, melaporkan bahwa penghimpunan dana Bank Umum dari masyarakat mencapai Rp.1.939,20 T, pada Mei 2016 mengalami kenaikan menjadi sebesar Rp.1.942,20 T. Sementara dari item penyaluran dana, pada November 2015 Bank Umum telah menyalurkan kredit kepada masyarakat sebesar 1.353,60 T, kemudian November 2016 mengalami penurunan menjadi sebesar $1.339,20 \mathrm{~T}$. Sedangkan dari indikator asset, Bank Umum di Indonesia pada November 2015 memiliki asset total sebesar Rp.2.310,60 T, kemudian pada November 2016 mengalami penurunan asset yang tidak siginifikan 
menjadi sebesar Rp.2.309,80 T. Selanjutnya, dari aspek permodalan, Bank Umum di Indonesia pada November 2015 memilki permodalan sebesar Rp.219,20 T, kemudian pada November 2016, permodalan Bank Umum mengalami kenaikan cukup siginifikan menjadi sebesar Rp.319,40 T. Terakhir dari item kinerja Bank Umum, pada November 2016 menunjukan bahwa Non Performing Loan (NPL) sebesar 3,80\% dan membukukan laba sebesar Rp.48,10 T dengan Net Interest Margin sebesar Rp.10,80 T

OJK (2016) melaporkan bahwa pada November 2016 terdapat 13 Bank Umum Syariah (BUS), 21 Unit Usaha Syariah (UUS), dan 164 Bank Pembiayaan Rakyat Syariah (BPRS). Hingga Februari 2017 jumlah BUS tidak mengalami peningkatan, demikian juga dengan UUS dan BPRS. Seiring dengan meningkatnya jaringan kantor bank, pada periode 2015-2016 industri ini mengalami peningkatan volume usaha (aset) cukup signifikan, dari Rp 272,343 triliun pada November 2015 menjadi Rp 339,343 triliun pada November 2016. Pada akhir tahun 2017 diproyeksikan pangsa perbankan syariah bisa mencapai tiga persen dengan nilai aset sekitar Rp 400 trilyun hingga Rp 450 triliun. Setidaknya ada tiga faktor pemicu pertumbuhan ini. Pertama, masuknya beberapa bank umum syariah (BUS) baru, kedua, pesatnya bisnis BUS lama, dan ketiga, target peningkatan bisnis Unit Usaha syariah (UUS) sekitar 40 hingga 50.

Penghimpunan dana pihak ketiga (DPK) perbankan syariah juga meningkat dari Rp 217,858 triliun pada November 2015 menjadi Rp 270,480 triliun pada November 2016. Kegiatan penyaluran dana melalui pembiayaan yang diberikan perbankan syariah juga meningkat dari Rp 212,996 triliun pada November 2015 menjadi Rp 240,381 triliun pada November 2016. Berdasarkan jenis penggunaannya, sebagian besar pembiayaan masih terfokus pada tiga jenis pembiayaan, yakni piutang murabahah 59,24 persen, pembiayaan mudharabah 19,96 persen, dan pembiayaan musyarakah sebesar 15,77 persen. Pertumbuhan pembiayaan yang masih cukup tinggi dalam kondisi sektor riil yang kurang kondusif akibat meningkatnya tekanan inflasi, berdampak pada meningkatnya jumlah pembiayaan bermasalah atau non-performing financing (NPF) (Makmun, 2008).

OJK (2016) melaporkan bahwa pada akhir 2015 NPF perbankan syariah bertahan pada level terkendali, rasio NPF (gross) sebesar 2,55 persen.
Namun, pada akhir 2017 meningkat menjadi 3,26 persen. Dari sesi profitabilitas, pada 2015 perbankan syariah mampu mencatatkan tingkat keuntungan $\mathrm{Rp}$ 1.786 miliar, meningkat menjadi Rp 2.771 miliar pada 2016. Sejalan dengan peningkatan profitabilitas ini, rasio keuntungan terhadap aset yang dikelola meningkat dari 0,49 persen pada 2016 menjadi 0,67 persen tahun 2017.

Di Indonesia konsep perbankan syariah mulai diterapkan sejak 1991 yang diawali dengan berdirinya Bank Muamalat Indonesia (BMI). Pada awal berdirinya, BMI belum mendapatkan perhatian yang luas. Dalam perjalanannya, terutama sejak MUI mengeluarkan fatwa haram terhadap bunga bank, bank berbasis Syariah bermunculan yang diikuti dengan munculnya lembaga keuangan berbasis syariah lainnya, seperti asuransi syariah, walaupun belum menjamur seperti bank syariah. Dalam tiga tahun terakhir industri perbankan syariah mengalami perkembangan yang pesat dan diiringi dengan meningkatnya kompleksitas permasalahan dan tantangan yang dihadapi.

Hal mendasar yang membedakan antara lembaga keuangan konvensional dengan syariah adalah terletak pada pengembalian dan pembagian keuntungan yang diberikan oleh nasabah kepada lembaga keuangan dan/atau yang diberikan oleh lembaga keuangan kepada nasabah (Muhammad, 2005). Kegiatan operasional bank syariah menggunakan prinsip bagi hasil (profit and loss sharing). Bank syariah tidak menggunakan bunga sebagai alat untuk memperoleh pendapatan maupun membebankan bunga atas penggunaan dana dan pinjaman karena bunga merupakan riba yang diharamkan.

Pola bagi hasil ini memungkinkan nasabah untuk mengawasi langsung kinerja bank syariah melalui monitoring atas jumlah bagi hasil yang diperoleh. Jumlah keuntungan bank semakin besar maka semakin besar pula bagi hasil yang diterima nasabah, demikian juga sebaliknya. Jumlah bagi hasil yang kecil atau mengecil dalam waktu cukup lama menjadi indikator bahwa pengelolaan bank merosot. Keadaan itu merupakan peringatan dini yang transfaran dan mudah bagi nasabah. Berbeda dari perbankan konvensional, nasabah tidak dapat menilai kinerja hanya dari indikator bunga yang diperoleh.

Kondisi perbankan syariah pada tahun mendatang diperkirakan akan terus membaik. Ini 
terbukti dengan masih tingginya minat masyarakat terhadap perbankan syariah. Dalam rangka peningkatan jangkauan melalui kemudahan untuk membuka kantor pelayanan, diharapkan dapat memberikan pengaruh pada minat masyarakat. Di sisi lain, secara internasional peluang memanfaatkan investasi asing, khususnya dari Timur Tengah ke dalam sistem perekonomian Indonesia masih terbuka lebar.

Pengembangan sistem perbankan syariah di Indonesia dilakukan dalam kerangka dual-banking system atau sistem perbankan ganda dalam kerangka Arsitektur Perbankan Indonesia (API), untuk menghadirkan alternatif jasa perbankan yang semakin lengkap kepada masyarakat Indonesia. Secara bersama-sama, sistem perbankan syariah dan perbankan konvensional secara sinergis mendukung mobilisasi dana masyarakat secara lebih luas untuk meningkatkan kemampuan pembiayaan bagi sektorsektor perekonomian nasional.

Karakteristik sistem perbankan syariah yang beroperasi berdasarkan prinsip bagi hasil memberikan alternatif sistem perbankan yang saling menguntungkan bagi masyarakat dan bank, serta menonjolkan aspek keadilan dalam bertransaksi, investasi yang beretika, mengedepankan nilai-nilai kebersamaan dan persaudaraan dalam berproduksi, dan menghindari kegiatan spekulatif dalam bertransaksi keuangan. Dengan menyediakan beragam produk serta layanan jasa perbankan yang beragam dengan skema keuangan yang lebih bervariatif, perbankan syariah menjadi alternatif sistem perbankan yang kredibel dan dapat dinimati oleh seluruh golongan masyarakat Indonesia tanpa terkecuali.

Dalam konteks pengelolaan perekonomian makro, meluasnya penggunaan berbagai produk dan instrumen keuangan syariah akan dapat merekatkan hubungan antara sektor keuangan dengan sektor riil serta menciptakan harmonisasi di antara kedua sektor tersebut. Semakin meluasnya penggunaan produk dan instrumen syariah disamping akan mendukung kegiatan keuangan dan bisnis masyarakat juga akan mengurangi transaksi-transaksi yang bersifat spekulatif, sehingga mendukung stabilitas sistem keuangan secara keseluruhan, yang pada gilirannya akan memberikan kontribusi yang signifikan terhadap pencapaian kestabilan harga jangka menengahpanjang.
Setelah diberlakukannya Undang-Undang No.21 Tahun 2008 tentang Perbankan Syariah yang terbit tanggal 16 Juli 2008, maka pengembangan industri perbankan syariah nasional semakin memiliki landasan hukum yang memadai dan akan mendorong pertumbuhannya secara lebih cepat lagi. Dengan progres perkembangannya yang impresif, yang mencapai rata-rata pertumbuhan aset lebih dari $65 \%$ pertahun dalam lima tahun terakhir, maka diharapkan peran industri perbankan syariah dalam mendukung perekonomian nasional akan semakin signifikan. Sehingga dapat dirumuskan masalah yaitu: (1) Apakah ada perbedaan siginifikan antara kinerja keuangan Perbankan Syariah dengan Perbankan Konvensional? (2) Apakah ada perbedaan signifikan antara tingkat efisiensi Perbankan Syariah dengan Perbankan Konvensional? dan (3)Apakah Perbankan Syariah lebih efisien dibandingkan dengan Perbankan Konvensional?

Tujuan yang ingin dicapai dalam penelitian ini adalah: (1) Mengetahui dan menguji perbedaan antara kinerja keuangan Perbankan Syariah dengan Perbankan Konvensional; (2) Untuk menganalisis dan menjelaskan perbedaan tingkat efisiensi antara Perbankan Syariah dengan Perbankan Konvensional dan (3) Menganalisis dan membandingkan tingkat efisiensi antara Perbankan Syariah dengan Perbankan Konvensional

\section{Kajian Pustaka dan Pengembangan Hipotesis Efisiensi}

Efisiensi merupakan tindakan memaksimalkan hasil dengan menggunakan modal (tenaga kerja, material dan alat) yang minimal (Daft, 2007; Griffin, 2004). Efisiensi merupakan rasio antara input dan output, dan perbandingan antara masukan dan pengeluaran. Apa saja yang dimaksudkan dengan masukan serta bagaimana angka perbandingan tersebut diperoleh, akan tergantung dari tujuan penggunaan tolok ukur tersebut. Secara sederhana, menurut Nopirin (1997) efisiensi dapat berarti tidak adanya pemborosan.

Efisiensi dalam penelitian ini sebagaimana dinyatakan oleh Talluri (2000) merupakan perbandingan output dan input berhubungan dengan tercapainya output maksimum dengan sejumlah input, artinya jika rasio output input besar maka efisiensi 
dikatakan semakin tinggi. Atau dengan kalimat lain, efisiensi adalah penggunaan input yang terbaik dalam memproduksi barang.

Menurut Talluri (2000); Cooper et al., (2002); Andersen dan Petersen (1993) efisiensi adalah rasio antara output dan input. Sedangkan menurut Banker et al., (1984) efisiensi merupakan salah satu kriteria penting dalam menentukan seberapa besar input yang digunakan untuk menghasilkan output yang diinginkan. Lebih lanjut Cooper et al., (2000); Andersen \& Petersen (1993) menjelaskan bahwa ada tiga faktor yang menyebabkan efisiensi, yaitu apabila dengan input yang sama menghasilkan output yang lebih besar dengan input yang lebih kecil menghasilkan output yang sama dan dengan input yang besar menghasilkan output yang lebih besar.

Yotopoulos dan Nugent (1976), Cooper et al., (2000) dan Talluri (2000); membedakan efisiensi menjadi tiga konsep yaitu:

(1) Efisiensi teknis (technical efficiency). Menurut Cooper et al., (2002); Bhat et al., (1996); Bowlin (1998) efisiensi teknik mengenai hubungan antara input dan output. Perusahaan dikatakan efisien secara teknik jika produksi dengan output terbesar yang menggunakan satu set kombinasi beberapa input;

(2) Efisiensi harga (allocative or price efficiency). Efisiensi alokatif menunjukkan hubungan biaya dan output. Efisiensi alokatif tercapai jika perusahaan tersebut mampu memaksimumkan keuntungan yaitu menyamakan produk marjinal setiap faktor produksi dengan harganya dan

(3) Efisiensi ekonomi (economic efficiency). Efisiensi ekonomi merupakan produk dari efisiensi teknik dan efisiensi harga. Jadi efisiensi ekonomis dapat dicapai jika kedua efisiensi tercapai.

Efisiensi ekonomis mempunyai sudut pandang makro yang mempunyai jangkauan lehih luas dibandingkan dengan efisiensi teknik yang bersudut pandang mikro. Pengukuran efisiensi teknik cenderung terbatas pada hubungan teknik dan operasional dalam proses konversi input menjadi output. Akibatnya, usaha untuk meningkatkan efisiensi teknis hanya memerlukan kebijakan mikro yang bersifat internal, yang dengan pengendalian dan alokasi sumber daya yang optimal. Dalam efisiensi ekonomis, harga tidak dapat dianggap given, karena harga dapat dipengaruhi oleh kebijakan makro (Nicholson, 1995).
Efisiensi ekonomis akan tercapai jika terpenuhi dua kondisi berikut (Doll \& Orazen, 1984) dalam Indah Susantun (2000) yaitu :

(1) Syarat yang diperlukan (necessary condition) menunjukkan hubungan fisik antara input dan output bahwa proses produksi antara 0 dengan 1. Hal ini merupakan efisiensi produksi secara teknik dan

(2) Syarat kecukupan (sufficient condition) berhubungan dengan tujuannya yaitu kondisi keuntungan maksimum tercapai dengan syarat nilai produk marjinal sama dengan biaya marjinal. Menurut Yotopoulos dan Lou (1973) dalam lndah Susantun (2000) efisiensi ekonomi tercapai jika kedua efisiensi yaitu teknik dan harga tercapai.

Efisiensi dapat diestimasi dengan teknik analisis Data Envelopment Analysis (DEA) yang memiliki karakter berbeda dengan konsep efisiensi pada umumnya (yang diestimasi dengan pendekatan parametrik). Ada beberapa alasan mengapa alat analisis $D E A$ dapat dipakai untuk mengukur efisiensi suatu proses produksi yaitu: (1) efisiensi yang diukur adalah bersifat teknis, bukan ekonomis. Hal ini dimaksudkan bahwa, analisis DEA hanya memperhitungkan nilai absolut dari suatu variabel. Satuan dasar pengukuran yang mencerminkan nilai ekonomis dari tiap-tiap variabel seperti harga, berat, panjang, isi dan lainnya tidak dipertimbangkan. Oleh karenanya dimungkinkan suatu pola perhitungan kombinasi berbagai variabel dengan satuan yang berbeda-beda; (2) nilai efisiensi yang dihasilkan bersifat relatif atau hanya berlaku dalam lingkup sekumpulan UKE (Unit Kegiatan Ekonomi) yang diperbandingkan (Talluri, 2000). Selanjutnya efisiensi untuk mengukur kinerja proses produksi dalam arti yang luas dengan mengoperasionalkan variabelvariabel yang mempunyai satuan yang berbeda-beda, yang kebanyakannya seperti dalam pengukuran barang-barang publik atau barang yang tidak mempunyai pasar tertentu (non-traded goods) maka alat analisis $D E A$ merupakan pilihan yang paling sesuai (Cooper et al., 2002).

\section{Data Envelopment Analysis (DEA)}

Data Envelopment Analysis (DEA) merupakan sebuah pendekatan non parametrik yang pada dasarnya merupakan teknik berbasis linier programming. $D E A$ bekerja dengan langkah mengidentifikasi unit-unit yang akan dievaluasi, input serta output unit tersebut. 
Kemudian menghitung nilai produktivitas dan mengidentifikasi unit mana yang tidak menggunakan input secara efisien atau tidak menghasilkan ouput secara efektif. Produktivitas yang diukur bersifat komparatif atau relatif karena hanya membandingkan antar unit pengukuran dari 1 set data yang sama. Dalam penelitian ini analisis $D E A$ ditujukan untuk mengukur efisiensi Perbankan konvesional maupun perbankan syariah (memfokuskan pada identifikasi penambahan output yang diperlukan untuk mencapai kondisi DEA dengan mempertahankan input yang dimiliki saat ini)

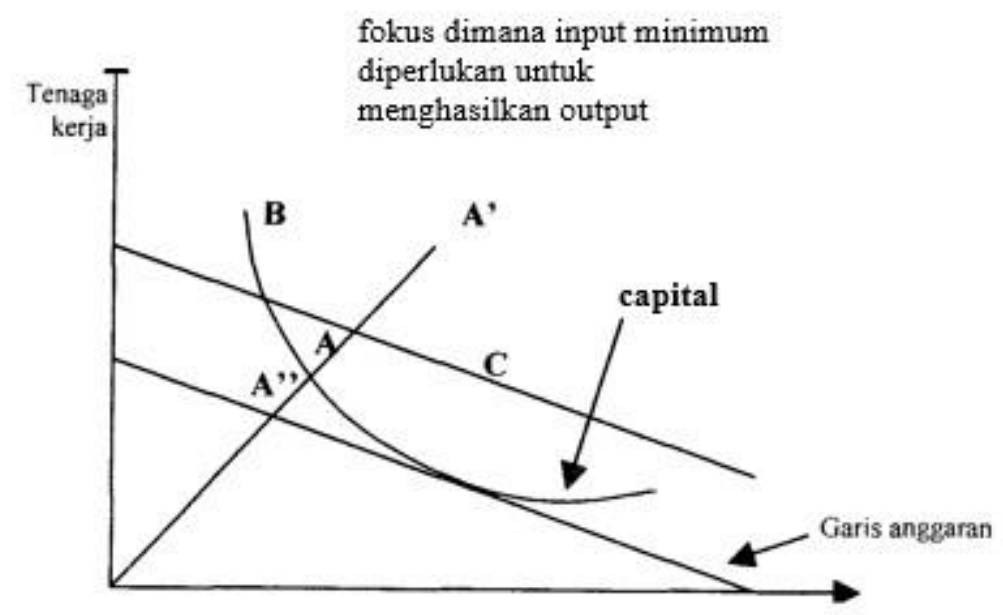

\section{Gambar 1. Konsep Efisiensi}

Titik A menunjukan efisiensi teknik tetapi pada titik A' jika menggunakan kombinasi input untuk memproduksi output yang sama, maka akan terjadi inefisiensi teknik karena menggunakan lebih banyak input dari yang dibutuhkan pada tingkat ouput efisiensi frontier. Titik B efisiensi teknik tetapi tidak efisien biaya karena pada tingkat ourput yang sama dapat memproduksi kurang dari biaya pada point C. Jika suatu organisasi bergerak dari titik A ke titik $\mathrm{C}$ efisiensi biaya akan meningkat (OA' - OA")/ OA'. Hal ini akan memperbaiki pengukuran efisiensi pada (OA' - OA) / OA dan efisiensi harga meningkat pada (OA OA") / OA. Efisiensi teknik biasanya diukur dengan melihat apakah input perlu dikurangi secara porposional untuk mencapai batas. Ini dikenal dengan nama konstrak radial input karena titik operasinya bergerak sepanjang garis dari titik origin sampai dimana organisasi berada.

Menurut Cooper et al. (2002) suatu perusahaan akan dapat dikatakan efisien apabila: (1) Mempergunakan jumlah unit input yang lebih sedikit dibandingkan jumlah unit input yang digunakan oleh perusahaan lain dengan menghasilkan jumlah output yang sama, (2) Menggunakan jumlah unit input yang sama, tetapi dapat menghasilkan jumlah output yang lebih besar.

$$
\text { Maksimisasi } \rightarrow h_{s}=\frac{\sum_{r=1}^{m} u_{r k} y_{r k}}{\sum_{i=1}^{n} v_{r k} x_{r k}}
$$

Dimana,

hs : adalah efisiensi teknik obyek s

$\mathrm{m}$ : adalah output obyek yang diamati

$\mathrm{n}$ : adalah input obyek yang diamati

$\mathrm{y}_{\mathrm{rk}}$ : merupakan jumlah output $\mathrm{r}$ yang

diproduksi oleh obyek $\mathrm{k}$

$\mathrm{x}_{\mathrm{rk}}$ : adalah jumlah input $\mathrm{r}$ yang digunakan

oleh obyek k

$\mathrm{u}_{\mathrm{rk}}$ : merupakan bobot output $\mathrm{r}$ yang

dihasilkan oleh obyek k

$\mathrm{v}_{\mathrm{rk}}$ : adalah bobot input $\mathrm{r}$ yang diberikan

oleh obyek k, dan r dihitung dari 1 ke m serta i ihitung dari $1 \mathrm{ke}$.

Persamaan diatas menunjukkan adanya penggunaan satu variabel input dan satu output. Rasio efisiensi $(h s)$, kemudian dimaksimalkan dengan kendala sebagai berikut (Talluri et al., 2000):

$$
\frac{\sum_{r=1}^{m} u_{r j} Y_{r j}}{\sum_{r=1}^{n} v_{i k} X_{i j}} \leq 1 ; \mathrm{j}=1, \ldots, \mathrm{N}
$$

Kriteria non-negatif,

$\mathrm{u}_{\mathrm{rk}} \geq 0 ; \mathrm{r}=1, \ldots \ldots ., m$

$\mathrm{V}_{\mathrm{rk}} \geq 0 ; 1=1, \ldots \ldots \ldots, n$

dimana, $\mathrm{N}$ menunjukkan jumlah obyek dalam sampel.

Pertidaksamaan pertama menunjukkan adanya efisiensi rasio untuk UKE lain tidak lebih dari 1, sementara pertidaksamaan kedua berbobot positif. Angka rasio akan bervariasi antara 0 sampai dengan 1. Obyek dikatakan efisien apabila memiliki angka rasio mendekati 1 atau 100 persen, sebaliknya jika mendekati 0 menunjukkan efisiensi obyek yang semakin rendah.

Beberapa bagian program linier ditransformasikan kedalam program ordinary linier 
secara primal sebagai berikut (Cooper et al., 2000; Talluri et al., 1997) :

Fungsi Tujuan:

$$
\begin{gathered}
(D E A) \text { Maksimumkan } \mathrm{hk}=\sum_{r=1}^{s} u_{y k} Y_{r k} \\
{\left[p_{k j} \sum_{r=1}^{s} u_{r k} y_{r k}-\sum_{i=1}^{m} v_{i k} X_{i j k} \leq 0 ; j=1, \ldots \ldots N\right.} \\
{\left[q_{k j} \sum_{i=1}^{m} v_{i k} X_{i j k}=1 \text { dimana } \mathrm{u}_{\mathrm{rk}} \text { dan } \mathrm{v}_{\mathrm{rk}} \geq 0\right.}
\end{gathered}
$$

Efisiensi pada masing-masing input dihitung menggunakan programasi linier dengan memaksimumkan jumlah output yang dibobot dari obyek $k$. Kendala jumlah input yang dibobot harus sama dengan satu untuk obyek $k$, sedangkan kendala untuk semua obyek, yaitu jumlah output yang dibobot dikurangi jumlah input yang dibobot harus kurang atau sama dengan 0. Hal ini berarti semua obyek akan berada atau dibawah referensi kinerja frontier yang merupakan garis lurus yang memotong sumbu origin (Purwantoro, 2003).

Dalam $D E A$, efisiensi dinyatakan dalam rasio antara total input tertimbang. Dimana setiap UKE diasumsikan bebas menentukan bobot untuk setiap variabel-variabel input maupun variabel output yang ada, asalkan mampu memenuhi dua kondisi yang disyaratkan yaitu (Cooper et al., 2000) :

(a) Bobot tidak boleh negatif

(b) Bobot harus bersifat universal atau tidak menghasilkan indikator efisiensi yang di atas normal atau lebih besar dari nilai 1 bilamana dipakai UKE yang lainnya.

Dalam rangka mencapai tingkat efisiensi yang maksimal, maka setiap UKE cenderung memiliki pola untuk menetapkan bobot tinggi pada input yang sedikit digunakan, dan pada output yang banyak dihasilkan. Dimana bobot yang dipilih tersebut tidak semata-mata menggambarkan suatu nilai ekonomis, tetapi lebih merupakan suatu kuantitatif rencana untuk memaksimalkan efisiensi UKE bersangkutan. Suatu UKE dikatakan efisien seeara relatif, bilamana nilai dualnya sama dengan 1 (nilai efisiensi $=100 \%$ ). Sebaliknya bila nilai dualnya kurang dari 1, maka UKE bersangkutan dianggap tidak efisien secara relatif (Bhat et al., 2003).

\section{Review Penelitian Terdahulu}

Penelitian yang dilakukan oleh Ascarya dan Yumanita (2007) dengan tujuan membandingkan tingkat efisiensi Perbankan Syariah di Indonesia dan Malaysia menunjukan hasil bahwa secara overall efficiency Perbankan Syariah di Indonesia memiliki tingkat efisiensi yang lebih tinggi (0,724) dibandingkan Malaysia (0,684). Sementara secara scale efficiency, Malaysia memiliki tingkat efisiensi $(0,919)$ yang lebih tinggi dibandingkan dengan Indonesia $(0,867)$. Untuk mengukur dan menganalisis tingkat efisiensi Perbankan Syariah Indonesia Dan Malaysia, peneliti menggunakan

Data Envelopment Analysis (DEA) dengan memasukan deposit, labor dan assets sebagai variabel input serta financing dan income sebagai variabel output.

Hasil penelitian Atmawardhana (2006) tentang analisis efisiensi Bank Umum Syariah dan Bank Umum Konvensional yang memiliki Unit Usaha Syariah di Indonesia menunjukan bahwa: (a) periode 1999-2004 tingkat efisiensi pada maksimal inputoutput dengan asumsi CRS, kedua kategori perbankan tersebut memiliki tingkat efisiensi yang sama yaitu $100 \%$ apabila dilakukan perhitungan dengan menggunakan bank yang efisien sebagai rujukan kepada bank yang belum efisien agar lebih efisien. Sehingga tidak ada perbedaan antara kedua perbankan tersebut, (b) Bank Umum Syariah yang memiliki tingkat efisiensi yang paling tinggi adalah Bank Syariah Mandiri dan diurutan berikutnya adalah Bank Mu'amalat Inodnesia (BMI). Penelitian menggunakan alat analisis Data Envelopment Analysis (DEA) dengan memasukan beban bunga/beban bagi hasil, biaya lainnya dan asset sebagai variabel input serta pendapatan bunga/pendapatan operasi utama, pendapatan lain-nya, dan kredit sebagai variable output.

\section{Metode Penelitian}

\section{Populasi dan Sampel Penelitian}

Populasi yang digunakan dalam penelitian ini adalah Bank Umum yang ada di Indonesia dengan jumlah 124 institusi bank dengan rincian 5 bank pemerintah dab 119 bank swasta. Institusi perbankan yang dijadikan sampel dalam penelitian adalah 5 institusi bank milik pemerintah (persero) dan 3 institusi bank umum syariah. Sampel secara rinci dapat dipaparkan dalam tabel sebagai berikut: 


\begin{tabular}{|c|c|c|}
\hline Keterangan & $\begin{array}{c}\text { Jumlah } \\
\text { Institusi } \\
\text { Bank }\end{array}$ & $\begin{array}{l}\text { Dipilih } \\
\text { Sebagai } \\
\text { Sampel }\end{array}$ \\
\hline 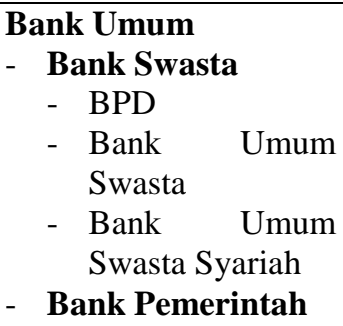 & $\begin{array}{l}26 \\
88 \\
12\end{array}$ & $\begin{array}{l}3 \\
5\end{array}$ \\
\hline $\begin{array}{lll}\text { Total } & \text { sampel } & \text { yang } \\
\text { dipilih } & & \end{array}$ & & 8 \\
\hline
\end{tabular}

\section{Data dan Sumber Data}

Sumber data yang diperlukan adalah data sekunder yang diperoleh dari Statistik Perbankan Syariah dan Statistik Perbankan Indonesia yang diterbitkan oleh Direktorat Perbankan Syariah Bank Indonesia periode Maret 2012 - Februari 2016, dengan periode publikasi laporan keuangan per-triwulan.

\section{Teknik Pengumpulan Data}

Pengumpulan data dilakukan dengan teknik pengumpulan data arsip (archival) yaitu teknik pengumpulan data di basis data (Jogiyanto, 2006)

\section{Definisi Operasional dan Pengukuran-nya}

Sekaran (2006); Jogiyanto (2003) menyatakan bahwa pengoperasionalan konsep (operationalizing the concept) atau disebut dengan mendefinisikan konsep secara operasi adalah men-jelaskan karakteristik dari obyek (properti) kedalam elemenelemer (elements) yang dapat diobservasi yang menyebabkan konsep dapat diukur dan dioperasionalkan di dalam riset.

Konsep secara operasi yang perlu didefiniskan adalam penelitian ini adalah:

(a) Ouput merupakan total dana (jumlah Rupiah) yang diperoleh dari financing (pembiayaan) dan income (laba sedang berjalan)

(b) Input adalah total dana (jumlah Rupiah) yang diperoleh dari deposit (dana pihak ketiga), labor (biaya tenaga kerja) dan assets (aktiva perusahan).

(c) Aspek permodalan dengan penilaian CAR (Capital Adequacy Ratio) yaitu modal inti dan modal pelengkap terhadap jumlah Aktiva Tertimbang Menurut Risiko (ATMR) atau secara singkat dapat diformulasikan sebagai berikut:

$$
C A R=\frac{\text { Modal }}{A T M R} \times 100 \%
$$

Dimana, Modal adalah modal inti dan modal pelengkap; CAR adalah Capital Adequacy Ratio; ATMR adalah aktiva tertimbang menurut risiko.

(d) ROA (Return On Assets) yaitu rasio laba terhadap total aktiva. Atau secara singkat dapat diformulasikan sebagai berikut:

$$
R O A=\frac{E B T}{T A} \times 100 \%
$$

Dimana, ROA adalah return on asset; EBT adalah laba sebelum pajak; dan TA adalah total asset.

(e) BOPO yaitu perbandingan biaya operasional dengan pendapatan operasional. Atau secara singkat dapat diformulasikan sebagai berikut:

$$
B O P O=\frac{T B O}{T P O} \times 100 \%
$$

Dimana, BOPO adalah biaya operasional-pendapatan operasional; TBO adalah total beban operasional; dan TPO adalah total pendapatan operasional.

(f) FDR (Financing to Deposits Ratio) yaitu perbandingan kredit yang diberikan dengan dana yang diterima. Atau secara singkat dapat diformulasikan sebagai berikut:

$$
F D R=\frac{T K}{D P K}
$$

Dimana, LDR adalah Loan to Deposits Ratio; TK adalah total kredit yang diberikan kepada pihak ketiga; dan DPK adalah dana pihak ketiga.

(g) Rasio NPL $=$ (Kredit dalam kualitas Kurang lancar, Diragukan dan Macet) / Total Kredit. Atau secara singkat dapat diformulasikan sebagai berikut:

$$
N P L=\frac{K M}{T K}
$$

Dimana, NPL adalah Non-Performing Loan; KM adalah kredit dalam kualitas macet; TK adalah total kredit yang diberikan kepada pihak ketiga

\section{Alat Analisis Data dan Pengujian}

Pengukuran efisiensi Perbankan Syariah dan Perbankan Konvensional menggunakan Data Envelopment Analysis (DEA), dengan memasukan 2 
variabel input yaitu: (i) deposit (dana pihak ketiga) dan (ii) labor (biaya personalia). Sedangkan variabel outputnya terdiri dari; (i) financing (besar dana pihak ke-tiga yang disalurkan ke masyarakat); (ii) income (laba sedang berjalan). Sedangkan untuk menganalisis ada tidak-nya perbedaan kinerja kedua kelompok bank menggunakan alat analisis dan pengujian $\mathrm{t}$ (t-test) dengan metode independet sample T-test. Selanjut-nya untuk menganalisis dan mengetahui ada tidak-nya perbedaan efisiensi (overall efficiency, tekhnical efficiency, dan scale efficiency) kelompok bank syariah dengan kelompok bank konvensional digunakan pengujian test group dengan menggunakan dua teknik pengujian yaitu parametrik meliputi: (i) anova test (signifikansi F) dan (ii) uji beda dua mean statistik (ttest) dan non-parametrik dengan menggunakan metode mann-whitney.

Kemudian untuk menganalisis kinerja keuangan bisa dilakukan dengan cara melakukan perhitungan rasio-rasio yang sumber-nya diperoleh dari angka-angka yang tecantum pada neraca keuangan dan laporan laba-rugi suatu bank, selanjutnya rasiorasio itu disebut sebagai rasio keuangan. Selanjutnya rasio keuangan digunakan sebagai dasar untuk mengetahui kinerja bank. Adapun perhitungan rasio keuangan yang digunakan dalam penelitian adalah, Capital adequacy ratio (CAR); Return on Asset (ROA); Biaya Operasional-Pendapatan Operasional (BOPO); Non-Performing Loan (NPL) dan Financing to Deposits Ratio (FDR).

\section{Hasil dan Pembahasan \\ Deskripsi Data, Kinerja Keuangan dan Data Output Input}

Sumber data penelitian ini berasal dari laporan keuangan bank, statistik perbankan syariah (SPS) dan statistik perbankan indonesia (SPI) periode Desember 2004 sampai dengan Desember 2008 yang dipublikasikan melalui website Bank Indonesia. Bank konvensional yang dipilih sebagai objek penelitian ini adalah Bank umum milik pemerintah atau bank persero yang terdiri dari Bank Mandiri (BM), Bank Negara Indonesia (BNI), Bank Rakyat Indonesia (BRI), dan Bank Tabungan Negara (BTN) serta perbankan syariah yang terdiri dari Bank Syariah Mandiri (BSM), Bank Muamalat Indonesia (BMI), dan Bank Syariah Mega Indonesia (BSMI).
Tabel 1. menunjukan kinerja bank konvensional (Panel A.) dan Bank Syariah (Panel B). Pengukuran kinerja didasarkan pada lima rasio keuangan bank, yaitu capital adequacy ratio (CAR), return on assets (ROA), biaya operasional terhadap pendapatan operasional (BOPO), non-performing loans (NPL) dan financing to deposit ratio (FDR). Dari sisi CAR, kinerja bank konvensional dari tahun ke tahun menunjukan tingkat kecukupan modal yang relatif stabil, titik terendah terjadi pada tahun 2008 yaitu sebesar 16,76 persen, namun masih jauh diatas batas mimimal yang ditetapkan Bank Indonesia yaitu sebesar 8 persen. Sementara kinerja bank syariah dari sisi CAR juga menunjukan trend yang sama dengan angka terendah terjadi pada tahun 2004 yaitu sebesar 10,28 persen. Sehingga dapat disimpulkan baik bank konvensional maupun bank syariah memiliki tingkat kecukupan modal yang aman dan relatif baik atau sehat, kerena CAR kedua perbankan tersebut lebih besar dari 8 persen.

Tabel 1. Kinerja Bank Syariah dan Bank Konvensional (Persen)

\begin{tabular}{|c|c|c|c|c|c|}
\hline 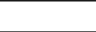 & 2012 & 2013 & 2014 & 2015 & 2016 \\
\hline \multicolumn{6}{|c|}{ Panel A. Bank Konvensioal } \\
\hline$C A R$ & 19,42 & 19,30 & 21,27 & 19,30 & 16,76 \\
\hline$R O A$ & 3,46 & 2,55 & 2,64 & 2,78 & 2,33 \\
\hline$B O P O$ & 76,64 & 89,50 & 86,98 & 84,05 & 88,59 \\
\hline$N P L$ & 5,88 & 14,75 & 10,70 & 6,50 & 3,74 \\
\hline FDR & 0,591 & 0,588 & 0,593 & 0,615 & 0,693 \\
\hline Kinerja & 86,5 & 72,0 & 74,0 & 86,5 & 90,0 \\
\hline \multicolumn{6}{|c|}{ Panel B. Bank Syariah } \\
\hline$C A R$ & 10,28 & 13,72 & 13,89 & 12,25 & 12,73 \\
\hline$R O A$ & 1,15 & 1,35 & 1,55 & 1,78 & 1,42 \\
\hline$B O P O$ & 75,47 & 78,91 & 76,77 & 76,54 & 81,75 \\
\hline$N P L$ & 2,37 & 2,82 & 4,75 & 4,05 & 3,95 \\
\hline$F D R$ & 0,944 & 0,955 & 0,947 & 0,948 & 0,986 \\
\hline Kinerja & 94,5 & 96,5 & 94,5 & 94,5 & 94,5 \\
\hline
\end{tabular}

konvensional menunjukan pergerakan angka yang relatif stabil, angka terendah terjadi pada tahun 2008, yaitu sebesar 2,33 persen, namun terletak di atas kisaran rasio yang ditetapkan oleh Bank Indonesia yaitu $1-2$ persen. Hal ini mengindikasi bahwa perolehan laba sebelum pajak (EBIT) atas penggunaan aset (rata-rata aset) relatif besar atau melebihi ketentuan yang ditetapkan Bank Indonesia, sehingga skor yang diperoleh bank konvensional dari sisi ROA belum mencapai 100 (skor yang dianggap sehat/baik). Misalnya, pada tahun 2008 ROA bank konvensional mencapai 2,33 persen, maka skor-nya adalah 90 sebagaimana ketentuan Bank Indonesia. Sementara posisi ROA bank syariah menunjukan level yang lebih 
baik dari bank konvensional, karena perkembangan ROA dari tahun ke-tahun mengindikasikan bahwa perbandingan laba sebelum pajak dengan aset perbankan berada pada posisi yang baik atau sehat, yaitu rasio berada pada kisaran $1-2$ persen. Sehingga dapat disimpulkan bahwa meskipun ROA bank konvensional lebih besar dari ROA bank syariah, namun kinerja EBIT atas aset bank syariah lebih sehat atau baik dari bank konvensional.

Kemudian dari sisi BOPO, baik kinerja bank konvensional maupun kinerja bank syariah menunjukan perkembangan biaya operasional yang tidak terlalu tinggi jika dibandingkan dengan pendapatan operasional-nya. Misalnya pada tahun 2008, posisi biaya operasional berbanding pendapatan operasional bank konvensional sebesar 88,59 persen yaitu berada pada kisaran 85 persen - 92 persen sesuai dengan ketentuan Bank Indonesia. Sementara bank syariah pada tahun yang sama mencapai sebesar 81,75 persen, masih di bawah standar yang ditentukan oleh Bank Indonesia. Sehingga dapat disimpulkan dari sisi BOPO, kinerja bank konvensional relatif lebih sehat dari kinerja bank syariah.

Lebih lanjut dari sisi NPL, perkembangan kredit bank konvensional dalam kualitas macet dari tahun ke-tahun menunjukan perubahan yang relatif fluktuatif, bahkan 'sempat' menembus angka yang sangat tinggi yaitu sebesar 14,75 persen. Hal ini menunjukan bahwa total kredit yang disalurkan kepada masyarakat berpotensi tidak mampu membayar dan mengembalikan bunga dan pokok pinjaman kepada bank konvensioal cukup besar yaitu 14,7 persen dari total kredit yang disalurkan kepada masyarakat. Sementara perkembangan NPL bank syariah dari tahun ke-tahun menunjukan kondisi yang sebaliknya, yaitu kredit kualitas macet yang dimiliki bank syariah relatif rendah. Misal-nya pada tahun 2008, NPL bank syariah hanya mencapai 3,95 persen, di bawah ketentuan NPL yang ditetapkan Bank Indonesia yaitu sebesar maksimal 5 persen. Sehingga dapat disimpulkan bahwa dari sisi NPL, kinerja bank syariah lebih baik atau sehat dari bank konvensional.

Terakhir, dari sisi FDR atau besar-nya total kredit yang disalurkan kepada masyarakat berbanding besar-nya dana yang dihimpun dari masyarakat (deposit atau dana pihak ke-tiga) menunjukan bahwa kinerja bank syariah lebih baik dari bank konvensional. Misal-nya pada tahun 2008, FDR bank syariah sebesar 98,6 persen berada pada kisaran yang ditetapakan oleh Bank Indonesia yaitu 85 persen - 110 persen. Hal ini menunjukan bahwa total dana pihak ketiga yang dimiliki bank syariah 98,6 persen-nya disalurkan kepada masyarakat untuk pembiayaan. Sementara pada tahun yang sama, FDR bank konvensional sebesar 69,3 persen, masih dibawah kisaran yang ditetapkan Bank Indonesia.

Secara keseluruhan (semua rasio), menunjukan bahwa bank syariah memiliki skor kinerja yang lebih tinggi dari bank konvensional. Misal-nya pada tahun 2008, skor kinerja bank syariah sebesar 94 (mendekati 100), sementara bank konvensioal pada tahun yang sama mencapai skor sebesar 90 persen. Hal ini menunjukan bahwa secara keseluruhan kinerja bank syariah lebih sehat dari bank konvensional.

\begin{tabular}{|c|c|c|c|c|c|}
\hline & 2012 & 2013 & 2014 & 2015 & 2016 \\
\hline \multicolumn{6}{|c|}{ Panel A. Bank Konvensioal } \\
\hline Deposit & 376.002 .416 & 431.076 .220 & 479.728 .795 & 571.888 .990 & 669.893 .884 \\
\hline Labor & 8.779 .597 & 9.886 .322 & 10.945 .000 & 13.071 .451 & 14.251 .053 \\
\hline Asset & 510.343 .081 & 556.545 .752 & 610.215 .289 & 725.716 .440 & 829.885 .425 \\
\hline Financing & 222.344 .040 & 253.593 .854 & 284.476 .529 & 351.710 .731 & 464.045 .959 \\
\hline Income & 11.508 .334 & 6.960 .488 & 9.016 .226 & 10.482 .631 & 12.924 .196 \\
\hline FDR & 0,591 & 0,588 & 0,593 & 0,615 & 0,693 \\
\hline \multicolumn{6}{|c|}{ Panel B. Bank Syariah } \\
\hline Deposit & 10.287 .039 & 13.714 .012 & 16.887 .817 & 20.798 .791 & 27.496 .903 \\
\hline Labor & 188.110 & 243.882 & 285.922 & 296.950 & 523.530 \\
\hline Asset & 12.508 .254 & 16.703 .617 & 19.922 .857 & 24.721 .122 & 32.756 .754 \\
\hline Financing & 9.706 .828 & 13.098 .130 & 15.985 .994 & 19.722 .258 & 27.098 .316 \\
\hline Income & 160.053 & 310.312 & 384.458 & 430.002 & 607.596 \\
\hline FDR & 0,944 & 0,955 & 0,947 & 0,948 & 0,986 \\
\hline \multicolumn{6}{|c|}{ Panel C. Bank Konvensional : Bank Syariah } \\
\hline Deposit & 36,55 & 31,43 & 28,41 & 27,50 & 24 \\
\hline Labor & 46,67 & 40,54 & 38,27 & 44,02 & 27,22 \\
\hline Asset & 40,80 & 33,32 & 30,63 & 29,36 & 25,33 \\
\hline Financing & 22,91 & 19,36 & 17,80 & 17,83 & 17,12 \\
\hline Income & 71,90 & 22,43 & 23,45 & 24,38 & 21,27 \\
\hline
\end{tabular}

Sumber: Data diolah berdasarkan Laporan Keuangan Bank Konvensional dan Bank Syariah periode 2012-2016 yang dipublikasikan melalui: www.bi.go.id

Tabel 2 menunjukan data output input yang digunakan untuk mengukur efisiensi bank konvensional dan bank syariah dengan metode data envelopment analysis (DEA). Data-data tersebut meliputi, deposit (dana pihak ke-tiga), labour (biaya personalia), asset bank, financing (pembiayaan) dan income (laba sedang berjalan). Berdasarkan tabel tersebut, nampak bahwa asset dan pembiayaan bank syariah dari tahun ke tahun mengalami peningkatan yang signifikan. Pada tahun 2004, aset bank syariah sebesar Rp.12,508 triliun, sementara pada tahun 2008 meningkat sebesar 162 persen yaitu menjadi Rp.32,757 triliun. Kemudian, pada tahun 2004, total kredit yang disalurkan kepada masyarakat sebesar 
Rp.9,707 triliun, tahun 2008 meningkat menjadi Rp.27,098.

Selanjutnya jika aset dan pembiayaan bank syariah dibandingkan dengan aset dan pembiayaan bank konvensional seperti nampak pada panel $\mathrm{C}$ tabel 4.2. menunjukan bahwa bank syariah jauh lebih kecil dari sisi aset maupun pembiayaan. Misal-nya pada tahun 2008, besar-nya aset bank konvensional 25,33 kali lebih besar dari aset bank syariah, sedangkan besar-nya financing bank konvensional 17,12 kali lebih besar dari bank syariah.

\section{Perbandingan Kinerja Keuangan (Hasil Pengujian t-test)}

Tabel 3 menunjukan ringkasan hasil pengujian Independent Sample T-test untuk mengetahui ada tidak-nya perbedaan dua mean, yaitu mean bank konvensional dan mean bank syariah. Dalam tabel tersebut nampak rata-rata CAR bank syariah $(12,57)$ yang lebih kecil dari rata-rata CAR bank konvensional $(19,21)$. Hal ini menunjukan dari sisi CAR, kinerja bank konvensional pada periode 2004-2008, lebih sehat (baik) dibandingkan dengan bank syariah, kerana semikin tinggi CAR mengindikasikan semakin besar kecukupan modal yang dimiliki oleh bank. Sementara, berdasarkan uji signifikansi $\mathrm{F}$ untuk CAR, diketahui karena F-sig $(0,920)$ lebih besar dari level of significant $(0,05)$, maka dapat disimpulkan bahwa varian bank syariah dengan varian bank konvensional sama. Berdasarkan uji siginifikansi t untuk CAR, diketahui karena t-sig $(0,000)$ lebih kecil dari level of significant $(0,05)$, maka dapat disimpulkan bahwa dilihat dari sisi CAR, kinerja bank syariah dengan bank konvensional berbeda secara signifikan.

\begin{tabular}{|c|c|c|c|c|c|c|c|c|c|}
\hline \multirow{3}{*}{$\begin{array}{c}\text { Rasio } \\
\text { Keuangan }\end{array}$} & \multicolumn{2}{|c|}{$\begin{array}{c}\text { Bank } \\
\text { Konvensional }\end{array}$} & \multicolumn{2}{|c|}{ Bank Syariah } & \multicolumn{5}{|c|}{ Pengujian Statistik } \\
\hline & \multirow[t]{2}{*}{ Mean } & \multirow{2}{*}{$\begin{array}{l}\text { Std. } \\
\text { Dev }\end{array}$} & \multirow[t]{2}{*}{ Mean } & \multirow{2}{*}{$\begin{array}{l}\text { Std. } \\
\text { Dev }\end{array}$} & \multicolumn{2}{|c|}{$\begin{array}{l}\text { Levene's Tets } \\
\text { for Equality of } \\
\text { Variance }\end{array}$} & \multicolumn{3}{|c|}{$\begin{array}{l}\text { t-test for equality of Means; } \\
\qquad \mathrm{df}=8, \alpha=95 \%\end{array}$} \\
\hline & & & & & F & Sig. & $\mathrm{T}$ & $\begin{array}{l}\text { Sig. 2- } \\
\text { tailed }\end{array}$ & $\begin{array}{c}\text { Mean } \\
\text { Diff }\end{array}$ \\
\hline CAR & 19,21 & 1,61 & 12,57 & 1,45 & 0,011 & 0,920 & 6,86 & 0,000 & 6,64 \\
\hline ROA & 2,75 & 0,43 & 1,45 & 0,23 & 0,805 & 0,396 & 5,96 & 0,000 & 1,30 \\
\hline $\mathrm{BOPO}$ & 85,15 & 5,19 & 77,88 & 2,49 & 1,809 & 0,216 & 2,82 & 0,022 & 7,26 \\
\hline NPL & 8,31 & 4,39 & 3,59 & 0,97 & 9,585 & 0,015 & 2,35 & 0,073 & 4,72 \\
\hline FDR & 0,62 & 0,0044 & 0,96 & 0,0017 & 1,966 & 0,198 & $-15,98$ & 0.000 & $-0,34$ \\
\hline Kinerja & 81,80 & 8,19 & 94,90 & 0,89 & 37,849 & 0,000 & $-3,556$ & 0,007 & $-13,10$ \\
\hline
\end{tabular}

Tabel 3 juga menginformasikan tentang perbedaan kinerja dari sisi ROA, yang menunjukan bahwa rata-rata ROA bank syariah $(1,45)$ lebih kecil dari rata-rata ROA bank konvensional $(2,75)$. Hal ini menjelaskan bahwa perolehan return atas penggunaan aset oleh bank konvensional lebih besar dari bank syariah, namun posisi ROA bank syariah masih berada pada posisi yang aman sebagaimana ketentuan Bank Indonesia, yang mensyaratkan ROA pada kisaran 1 persen -2 persen. Sementara, berdasarkan uji signifikansi F untuk ROA, diketahui karena F-sig $(0,396)$ lebih besar dari level of significant $(0,05)$, maka dapat disimpulkan bahwa varian bank syariah dengan varian bank konvensional sama. Berdasarkan uji siginifikansi t untuk ROA, diketahui karena t-sig $(0,000)$ lebih kecil dari level of significant $(0,05)$, maka dapat disimpulkan bahwa dilihat dari sisi ROA, kinerja bank syariah dengan bank konvensional berbeda secara signifikan.

Selanjut-nya tabel 4.3. juga mendeskripsikan tentang perbedaan kinerja dari sisi rasio biaya operasional dan pendapatan operasional (BOPO), yang menunjukan bahwa rata-rata BOPO bank konvensional $(85,15)$ lebih besar dari BOPO yang dicapai oleh bank syariah $(77,88)$. Hal ini menjelaskan bahwa dari sisi BOPO, kinerja bank konvensional lebih baik (sehat) dari bank syariah. Sementara posisi BOPO yang dicapai oleh bank syariah berada di bawah ketentuan Bank Indonesia yang mensyaratkan kisaran angka BOPO sebesar 85 persen - 92 persen. Berdasarkan uji signifikansi F untuk BOPO, diketahui karena F-sig $(0,216)$ lebih besar dari level of significant $(0,05)$, maka dapat disimpulkan bahwa varian bank syariah dengan varian bank konvensional identik. Berdasarkan uji siginifikansi t untuk BOPO, diketahui karena t-sig $(0,022)$ lebih kecil dari level of significant $(0,05)$, maka dapat disimpulkan bahwa dilihat dari sisi BOPO, kinerja bank syariah dengan bank konvensional berbeda secara signifikan.

Kemudian dari sisi rasio kredit kualitas macet dengan total kredit yang disalurkan (NPL), menunjukan bahwa rata-rata NPL bank konvensional $(8,31)$ lebih tinggi dari NPL bank syariah $(3,59)$, artinya proporsi kredit kualitas macet yang dimiliki bank konvensional lebih besar dari proporsi kredit kualitas macet yang dimiliki bank syariah. Berdasarkan uji signifikansi $\mathrm{F}$ untuk NPL, diketahui karena F-sig $(0,015)$ lebih kecil dari level of significant $(0,05)$, maka dapat disimpulkan bahwa varian bank syariah dengan varian bank konvensional berbeda. Berdasarkan uji siginifikansi t untuk NPL, diketahui karena t-sig $(0,073)$ lebih besar dari level of 
significant $(0,05)$, maka dapat disimpulkan bahwa dilihat dari sisi NPL, kinerja bank syariah dengan bank konvensional tidak berbeda (sama).

Terakhir, tabel 3 juga menjelaskan tentang perbedaan kinerja dari sisi rasio financing dan deposit of fund. Dalam tabel tersebut nampak bahwa rata-rata FDR bank syariah $(0,96)$ lebih besar dari rata-rata bank konvensional $(0,62)$ artinya bank syariah memiliki proporsi dana pihak ketiga yang disalurkan ke masyarakat lebih besar dari bank konvensional. Berdasarkan uji signifikansi $F$ untuk FDR, diketahui karena F-sig $(0,198)$ lebih besar dari level of significant $(0,05)$, maka dapat disimpulkan bahwa varian bank syariah dengan varian bank konvensional sama. Berdasarkan uji siginifikansi t untuk FDR, diketahui karena t-sig $(0,00)$ lebih kecil dari level of significant $(0,05)$, maka dapat disimpulkan bahwa dilihat dari sisi FDR, kinerja bank syariah dengan bank konvensional berbeda secara signifikan.

Secara keseluruhan (semua rasio), rata-rata kinerja bank syariah $(94,90)$ lebih besar dari rata-rata kinerja bank konvensional $(81,80)$, sehingga dapat disimpulkan kinerja bank syariah relatif sehat dibandingkan dengan bank konvensional. Berdasarkan uji signifikansi $\mathrm{F}$ untuk kinerja, diketahui karena F-sig $(0,000)$ lebih kecil dari level of significant $(0,05)$, maka dapat disimpulkan bahwa varian bank syariah dengan varian bank konvensional berbeda. Berdasarkan uji siginifikansi t untuk kinerja, diketahui karena t-sig $(0,007)$ lebih kecil dari level of significant $(0,05)$, maka dapat disimpulkan bahwa dilihat dari semua rasio (kinerja), kinerja bank syariah dengan bank konvensional berbeda secara signifikan.

\section{Perbandingan Efisiensi}

Tabel 4 menunjukan hasil pengujian parametrik dan non parametrik untuk mengetahui ada tidak-nya perbedaan efisiensi (overall efficiency, tekhnical efficiency, dan scale efficiency) kelompok bank syariah dengan kelompok bank konvensional. Pengujian ini disebut juga sebagai test group dengan menggunakan dua teknik pengujian yaitu parametrik meliputi: (i) anova test (signifikansi F) dan (ii) uji beda dua mean statistik $\left(\mathrm{t}_{\text {-test }}\right)$ dan non-parametrik dengan menggunakan metode mann-whitney.
Tabel 4. Hasil Pengujian Parametrik dan Non-Parametrik

\begin{tabular}{lccc}
\multicolumn{1}{c}{ Item } & \multicolumn{3}{c}{ Test Group } \\
\cline { 2 - 4 } \multicolumn{1}{c}{ Parametric } & Non Parametric \\
\hline Individual Test & ANOVA Test & t-test & Mann-Whitney \\
Hypothesis & MeanBS=MeanBK & & MedianBS=MedianBK \\
Test Statistic & $\mathrm{F}(\mathrm{Prb}>\mathrm{F}-\mathrm{Sig})$ & $\mathrm{t}(\mathrm{Prb}>\mathrm{t}-\mathrm{Sig})$ & $\mathrm{z}(\mathrm{Prb}>\mathrm{z}-\mathrm{Sig})$ \\
Overall Efficiency & 0,045 & 0,045 & 0,004 \\
Technical Efficiency & 0,026 & 0,023 & 0,006 \\
Scale Efficiency & 0,003 & 0,042 & 0,018 \\
\hline
\end{tabular}

Sumber: Output Pengolahan Data

Berdasarkan uji signifikansi $\mathrm{F}$ untuk rata-rata overall efficiency ke-dua kelompok bank, diketahui karena F-sig $(0,045)$ lebih kecil dari level of significant $(0,05)$, maka dapat disimpulkan bahwa varian overall efficiency bank syariah dengan varian overall efficiency bank konvensional berbeda secara signifikan. Sedangkan berdasarkan hasil pengujian siginifikansi $\mathrm{t}$ untuk perbedaan dua mean, diketahui karena t-sig $(0,045)$ lebih kecil dari level of significant $(0,05)$, maka dapat disimpulkan bahwa rata-rata overall efficiency bank syariah dengan rata-rata overall efficiency bank konvensional berbeda secara signifikan. Sementara berdasarkan hasil pengujian non parametrik (mann-withney) untuk perbedaan dua median, diketahui karena z-sig $(0,004)$ lebih kecil dari level of significant $(0,05)$, maka dapat disimpulkan bahwa median overall efficiency bank syariah dengan median overall efficiency bank konvensional berbeda secara signifikan.

Selanjutnya merujuk pada item technical efficiency ke-dua kelompok bank, diketahui karena Fsig $(0,026)$ lebih kecil dari level of significant $(0,05)$, maka dapat disimpulkan bahwa varian technical efficiency bank syariah dengan varian technical efficiency bank konvensional berbeda secara signifikan. Sedangkan berdasarkan hasil pengujian siginifikansi $\mathrm{t}$ untuk perbedaan dua mean, diketahui karena t-sig $(0,023)$ lebih kecil dari level of significant $(0,05)$, maka dapat disimpulkan bahwa rata-rata technical efficiency bank syariah dengan rata-rata technical efficiency bank konvensional berbeda secara signifikan. Sementara berdasarkan hasil pengujian non parametrik (mann-withney) untuk perbedaan dua median, diketahui karena z-sig $(0,006)$ lebih kecil dari level of significant $(0,05)$, maka dapat disimpulkan bahwa median technical efficiency bank syariah dengan median technical efficiency bank konvensional berbeda secara signifikan.

Berikut-nya merujuk pada item scale efficiency ke-dua kelompok bank, diketahui karena F-sig $(0,003)$ lebih kecil dari level of significant $(0,05)$, maka dapat disimpulkan bahwa varian scale efficiency bank 
syariah dengan varian scale efficiency bank konvensional berbeda secara signifikan. Sedangkan berdasarkan hasil pengujian siginifikansi $\mathrm{t}$ untuk perbedaan dua mean, diketahui karena t-sig $(0,042)$ lebih kecil dari level of significant $(0,05)$, maka dapat disimpulkan bahwa rata-rata scale efficiency bank syariah dengan rata-rata scale efficiency bank konvensional berbeda secara signifikan. Sementara berdasarkan hasil pengujian non parametrik (mannwithney) untuk perbedaan dua median, diketahui karena z-sig $(0,018)$ lebih kecil dari level of significant $(0,05)$, maka dapat disimpulkan bahwa median scale efficiency bank syariah dengan median scale efficiency bank konvensional berbeda secara signifikan.

\section{Hasil Pengujian Data Envelpment Analysis (DEA)}

Tabel 5 menunjukan ringkasan statistik hasil pengukuran efisiensi dengan menggunakan metode DEA terhadap bank syariah dan bank konvensional, yang meliputi Panel A (2004), Panel B (2005), Panel C (2006), Panel D (2007), Panel E (2008) dan Panel F (semua tahun). Perlu diketahu bahwa obyek dikatakan efisien apabila memiliki angka rasio mendekati 1 atau 100 persen, sebaliknya jika mendekati 0 menunjukkan efisiensi obyek yang semakin rendah.

Sebagai misal, Pada Panel A tabel tersebut nampak bahwa rasio overall efficiency bank syariah $(0,947)$ lebih tinggi dari bank konvensional $(0,723)$. Sehingga dapat disimpulkan bahwa pada tahun 2004, kegiatan ekonomi (perbankan) bank syariah lebih efisien dibandingkan dengan bank konvensional, kerena rasio efisiensi bank syariah mendekati 1 (100 persen). Sementara pada periode 2008 (Panel E) rasio kelompok bank syariah meningkat menjadi 0,956 masih dalam posisi lebih besar dari rasio efisiensi bank konvensional $(0,756)$. Sehingga dapat disimpulkan bahwa pada tahun 2008, kegiatan ekonomi (perbankan) bank syariah lebih efisien dibandingkan dengan bank konvenasional.

\begin{tabular}{|c|c|c|c|c|}
\hline Efficiency Measures & Mean & Minimum & Maximum & Std Dev \\
\hline \multicolumn{5}{|c|}{ Panel A. 2012} \\
\hline \multicolumn{5}{|l|}{ Bank Konvensional } \\
\hline Overall Efficiency & 0,723 & 0,295 & 1,000 & 0,243 \\
\hline Technical Efficiency & 0,832 & 0,346 & 1,000 & 0,222 \\
\hline Scale Efficiency & 0,862 & 0,581 & 1,000 & 0,133 \\
\hline \multicolumn{5}{|l|}{ Bank Syariah } \\
\hline Overall Efficiency & 0,947 & 0,366 & 1,000 & 0,232 \\
\hline Tekhnical Efficiency & 0,993 & 0,949 & 1,000 & 0,019 \\
\hline Scale Efficiency & 0,953 & 0,366 & 1,000 & 0,229 \\
\hline \multicolumn{5}{|c|}{ Panel B. 2013} \\
\hline \multicolumn{5}{|l|}{ Bank Konvensional } \\
\hline Overall Efficiency & 0,734 & 0,245 & 1,000 & 0,284 \\
\hline Technical Efficiency & 0,809 & 0,288 & 1,000 & 0,247 \\
\hline Scale Efficiency & 0,897 & 0,527 & 1,000 & 0,169 \\
\hline \multicolumn{5}{|l|}{ Bank Syariah } \\
\hline Overall Efficiency & 0,955 & 0,333 & 1,000 & 0,224 \\
\hline Tekhnical Efficiency & 0,927 & 0,476 & 1,000 & 0,172 \\
\hline Scale Efficiency & 0,907 & 0,699 & 1,000 & 0,117 \\
\hline \multicolumn{5}{|c|}{ Panel C. 2014} \\
\hline \multicolumn{5}{|l|}{ Bank Konvensional } \\
\hline Overall Efficiency & 0,748 & 0,323 & 1,000 & 0,229 \\
\hline Technical Efficiency & 0,810 & 0,328 & 1,000 & 0,208 \\
\hline Scale Efficiency & 0,919 & 0,630 & 1,000 & 0,135 \\
\hline \multicolumn{5}{|l|}{ Bank Syariah } \\
\hline Overall Efficiency & 0,955 & 0,437 & 1,000 & 0,187 \\
\hline Tekhnical Efficiency & 0,921 & 0,659 & 1,000 & 0,130 \\
\hline Scale Efficiency & 0,951 & 0,663 & 1,000 & 0,103 \\
\hline \multicolumn{5}{|c|}{ Panel D. 2015} \\
\hline \multicolumn{5}{|l|}{ Bank Konvensional } \\
\hline Overall Efficiency & 0,742 & 0,068 & 1,000 & 0,270 \\
\hline Technical Efficiency & 0,807 & 0,071 & 1,000 & 0,250 \\
\hline Scale Efficiency & 0,919 & 0,520 & 1,000 & 0,150 \\
\hline \multicolumn{5}{|l|}{ Bank Syariah } \\
\hline Overall Efficiency & 0,948 & 0,338 & 1,000 & 0,200 \\
\hline Tekhnical Efficiency & 0,918 & 0,461 & 1,000 & 0,158 \\
\hline Scale Efficiency & 0,919 & 0,622 & 1,000 & 0,128 \\
\hline \multicolumn{5}{|c|}{ Panel E. 2016} \\
\hline \multicolumn{5}{|l|}{ Bank Konvensional } \\
\hline Overall Efficiency & 0,756 & 0,368 & 1,000 & 0,254 \\
\hline Tekhnical Efficiency & 0,887 & 0,371 & 1,000 & 0,263 \\
\hline Scale Efficiency & 0,848 & 0,620 & 1,000 & 0,175 \\
\hline \multicolumn{5}{|l|}{ Bank Syariah } \\
\hline Overall Efficiency & 0,956 & 0,338 & 1,000 & 0,219 \\
\hline Technical Efficiency & 0,925 & 0,461 & 1,000 & 0,158 \\
\hline Scale Efficiency & 0,945 & 0,622 & 1,000 & 0,178 \\
\hline \multicolumn{5}{|c|}{ Panel F. All Year } \\
\hline \multicolumn{5}{|l|}{ Bank Konvensional } \\
\hline Overall Efficiency & 0,684 & 0,059 & 1,000 & 0,255 \\
\hline Technical Efficiency & 0,750 & 0,059 & 1,000 & 0,253 \\
\hline Scale Efficiency & 0,819 & 0,530 & 1,000 & 0,143 \\
\hline \multicolumn{5}{|l|}{ Bank Syariah } \\
\hline Overall Efficiency & 0,924 & 0,171 & 1,000 & 0,219 \\
\hline Technical Efficiency & 0,930 & 0,332 & 1,000 & 0,197 \\
\hline Scale Efficiency & 0,967 & 0,376 & 1,000 & 0,163 \\
\hline
\end{tabular}

Tabel 5 panel $\mathrm{F}$ juga menginformasikan tentang efisiensi kegiatan perbankan bagi kelompok bank syariah dan kelompok bank konvensional untuk periode 2004-2008 (semua periode pengamatan). Dalam tabel tersebut nampak bahwa rasio overall efficiency bank konvensional $(0,648)$ lebih besar dari rasio overall efficiency $(0,924)$; rasio technical efficiency bank syariah $(0,930)$ lebih besar dari rasio technical efficiency bank konvensional $(0,750)$; dan rasio scale efficiency bank syariah $(0,967)$ lebih besar dari rasio scale efficiency bank konvensional $(0,819)$. Sehingga dapat disimpulkan bahwa sepanjang periode pengamatan yaitu dari tahun 2004 sampai dengan 
2008, kegiatan ekonomi (perbankan) bank syariah relatif lebih efisien dari bank konvensional.

\section{Simpulan}

Mengacu pada tujuan penelitian ini dan jawaban atas tujuan penelitian yang dibahas dalam bab "pembahasan hasil" dapat diambil beberapa kesimpulan bahwa:

(1) Secara keseluruhan (semua rasio keuangan yang diamati), menunjukan bahwa bank syariah memiliki skor kinerja yang lebih tinggi dari bank konvensional. Hal ini menunjukan bahwa kinerja bank syariah lebih baik (sehat) dari bank konvensional.

(2) Sepanjang periode pengamatan, rata-rata kinerja bank syariah lebih besar dari rata-rata kinerja bank konvensional sehingga dapat disimpulkan kinerja bank syariah relatif lebih baik (sehat) dibandingkan dengan bank konvensional.

(3) Berdasarkan uji signifikansi F untuk kinerja, dapat disimpulkan bahwa varian bank syariah dengan varian bank konvensional berbeda. Berdasarkan uji siginifikansi t untuk kinerja, dapat disimpulkan bahwa dilihat dari semua rasio (kinerja), kinerja bank syariah dengan bank konvensional berbeda secara signifikan.

(4) Berdasarkan uji signifikansi F untuk rata-rata overall efficiency ke-dua kelompok bank, dapat disimpulkan bahwa varian overall efficiency bank syariah dengan varian overall efficiency bank konvensional berbeda secara signifikan. Sedangkan berdasarkan hasil pengujian siginifikansi t untuk perbedaan dua mean dapat disimpulkan bahwa rata-rata overall efficiency bank syariah dengan rata-rata overall efficiency bank konvensional berbeda secara signifikan.

(5) Sementara berdasarkan hasil pengujian non parametrik (mann-withney) untuk perbedaan dua median dapat disimpulkan bahwa median overall efficiency bank syariah dengan median overall efficiency bank konvensional berbeda secara signifikan.

(6) Berdasarkan hasil pengujian dengan metode DEA, sepanjang periode pengamatan yaitu dari tahun 2004 sampai dengan 2008, kegiatan ekonomi (perbankan) bank syariah relatif lebih efisien dari bank konvensional.

\section{Implikasi Kebijakan}

Kinerja dan efisiensi bank syariah menunjukan perkembangan yang positif dan konstruktif, namun pangsa (share) Perbankan Syariah dari sisi aset, deposit fund dan kredit terhadap total Bank terhitung sangat kecil yaitu dibawah 3\%, serta share tersebut berkembang melambat dari tahun ke tahun atau belum tumbuh secara signifikan. Sehingga diperlukan langkah-langkah strategis bagi pengambil kebijakan yang terkait dengan pengembangan Perbankan Syariah di Indonesia, yaitu:

(1) Bank syariah harus berupaya memenuhi kebutuhan perbankan nasabah/deposan sebagaimana yang sudah dinikmati dari bank konvensional;

(2) Meningkatkan kualitas layanan perbankan syariah sehingga dapat memenuhi standar kualitas layanan sebagaimana yang didapatkan di bank konvensional

(3) Meningkatkan jumlah kantor cabang, kantor cabang pembantu kantor kas Bank Syariah, sehingga mudah ditemukan oleh deposan/nasabah;

(4) Bank syariah harus secara ketat menjalankan prinsip syariah (prioritas pertama), pelayanan yang cepat (peringkat kedua), pelayanan yang ramah (prioritas ketiga), pengelola yang profesional (prioritas keempat), dan pengetahuan pegawai bank syariah tentang produk bank syariah (prioritas kelima);

Peneliti tidak berpretensi bahwa penelitian tentang perbankan syariah ini, telah menghasilkan output penelitian yang sempurna ke-akurasian-nya, namun ada beberapa keterbatasan yang bisa diidentifikasi yaitu:

(1) Hasil penelitian belum mengungkapkan faktor apa saja yang menyebabkan perbedaan kinerja dan efisiensi kedua kelompok bank tersebut.

(2) Periode pengamatan hanya lima tahun (20042008) dan observer bank konvensional hanya terbatas pada kelompok bank persero

(3) Hasil penelitian ini tidak bisa menjelaskan faktorfaktor apa yang mempengaruhi pangsa (share) asset, deposit fund dan financing extended perbankan Syariah sangat kecil, jika dibandingan dengan total perbankan di Indonesia.

(4) Hasil penelitian belum menjelaskan item-item kinerja dan output-input efisiensi yang 
memberikan kontribusi terhadap efisiensi kedua kelompok bank

\section{Referensi}

[1] Antonio, M.S. (2001), "Bank Syariah: Dari Teori Ke Praktek". Gema Insani Press dan Tazkia Cendekia. Jakarta.

[2] Budisantoso, T. dan Triandaru, S. (2006), "Bank dan Lembaga Keuangan Lain”, Salemba Empat. Jakarta

[3] Direktorat Perbankan Syariah BI (2008), "Statistik Perbankan Syariah". http/www.bi.co.id/

[4] Hartono, J. (2004), "Metodologi Penelitian Bisnis: Salah Kaprah dan PengalamanPengalaman". BPFE-UGM. Jogjakarta

[5] Ismal, R. (2008), "Syariah Untuk Kelebihan Likuiditas", Opini Republika. PT Republika Mandiri. Jakarta

[6] Karim, A.A. (2008), "Bank Islam: Analisis Fiqih dan Keuangan”, Edisi Ketiga. PT Rajagrafindo Persada. Jakarta

[7] Karim, A.A. (2008), "Momentum Emas Perbankan Syariah", Opini Republika. PT Republika Mandiri. Jakarta

[8] Lewis, M.K. dan AlGaoud, L.M. (2007), "Perbankan Syariah: Prinsip, Praktik dan Prospek". PT Serambi Ilmu Semesta. Jakarta

[9] Makmun (2008), "Tantangan Perbankan Syariah", Opini Republika. PT Republika Mandiri. Jakarta

[10] Muhamad (2008), “Keuangan Islami”. Edisi Pertama. EKONISIA FE-UII. Yogyakarta

[11] Sekaran, U. (2006), "Metodologi Untuk Bisnis". Terjemahan. Salemba Empat. Jakarta. 